TURIZAM

Volume 21 , Issue 2

$65-80$ (2017)

ORIGINAL

SCIENTIFIC PAPER

\title{
Rural Areas Under the Pressure of Industrialization Process - A Sustainable Rural Tourism Model Proposal for Kandira Residential Area
}

\author{
Ibrahim Cetin ${ }^{A}$, Orhan Icoz ${ }^{B}$, Tulay Polat Uzumcu ${ }^{C}$ \\ Received: February 2017 | Accepted: Jun 2017 \\ DOI: 10.18421/TRZ21.02-01
}

\begin{abstract}
Agriculture, as a traditional food production area, has played a key role in the development of societies for many years throughout the history. But, rural areas have been neglected by humans due to the inevitable consequence of industrial revolution for many years. Consequently, city settlements attracted many rural inhabitants owing to the social and cultural changes, which turned rural areas into the unproductive idle areas. Thus, these areas faced with the danger of losing their attractiveness due to the increasing production costs and inefficient use of arable lands. Within this scope, thanks to the development of tourism industry, these areas have gained their importance once again. For rational utilization of tourism development by the tourist attractions, tourism strategies need to be redesigned in a sustainable way considering such factors as the preservation-utilization balance of land uses. The purpose of this evaluative study is to reveal the opinion on the ways of tourism development as an alternative in the socio-economic development of rural areas. Within this context, it was aimed to develop and suggest a sustainable tourism model for Kandira town, with its high rural tourism potential depending on the natural and unspoilt rural areas within the borders of Kocaeli as an industrial city.
\end{abstract}

Key Words: Industrialization, rural tourism, tourism planning, sustainability, Kandira.

\section{Introduction}

Agriculture and livestock farming played an important role in the development of countries in human history as essential economic activity. But the agriculture as a basic sector was started to lose its economic importance after the industrial revolution in western countries. Consequently, as some of the countries and particular areas within these countries were more developed economically and socially than other countries and rural areas whose production were primarily based on agriculture, and accordingly engaged in agriculture, couldn't get sufficient

\footnotetext{
Yuzuncu Yil University, Van, Turkey, e-mail: ibrahimcetino1@yahoo.com

Yasar University, Izmir, Turkey, e-mail: orhan.icoz@yasar.edu.tr

Kocaeli University, Kocaeli,Turkey, e-mail: tulay.uzumcu@kocaeli.edu.tr
} 
benefits from this development. Economic and social development moving from rural areas to industrial centres within this process worsened the economic and social standards of rural inhabitants, and as a result of poor life standards, it increased their losses by leading to changes in their social and cultural structure.

Increasing leisure time resulting from the rising economic and social welfare as a result of industrial development along with the technological support has caused a massive increase in the number of travels, which was relatively low prior to 1950 's, by leading people to move through coastal areas (Bahce, 2009). As known, mass tourism can easily be evolved when products are supplied as package tours to the less developed destinations countries from the developed generating areas. Although tourism emerges in coastal areas, it also develops mainly depending on cultural, historical and natural attractions (such as seas, lakes, forests, wetlands, floras). However, it was observed that the demand moves towards 'alternatives' when the development of mass tourism causes the significant harmful effects on the natural areas. The importance of some changes in tourism demand was mentioned by the authors Briedenhann and Wickens (2004) and Hudman (1992). This demand headed for some alternative tourism types such as eco-tourism (Orams, 1995: 4) which provides a more meaningful experience owing to the flexible and individualized features than traditional mass tourism (Briedenhann, Wickens, 2004). In contrast to mass tourism, the change in demand has created a growing tendency towards rural areas and hinterlands rather than coasts.

The economic development of a region as a whole mostly depends on some factors as natural resources, capital, labour, technology, entrepreneurship and infrastructure that are necessary for any investment in the region. The unbalanced distribution of these resources is seen as a reason for the emergence of less developed countries and even less developed areas within a specific country. The countryside areas, described as rural areas at the same time, have lack of alternatives for development but agricultural production activities, and they are confined to traditional production styles and agriculture to survive (Cetin, 2015). However, as a result of the long term changes in demand, it has been observed that tourism could be an effective tool for economic and social development in rural areas, as an alternative for economic diversity and an alternative to the regional industries that cannot be developed in these areas due to their inadequate resources. This is because of the fact that tourism depends heavily on natural, social and cultural resources everywhere and the distribution of natural resources is relatively well balanced all around the world in comparison to other resources for industrial production. In addition to above discussion, every rural area or village may own their unique culture and lifestyle that may create specific attractions for potential visitors. Considering the fact that natural and cultural values are the main resources for tourism, which are geographically distributed in a fairly and more balanced way (Met, 2012), it can be concluded that the development of tourism in rural areas could be very rational when rural tourism supply is well planned by taking the recent trends in demand into consideration.

\section{Literature Review}

In the literature, the economic and social benefits of rural tourism have widely been discussed and examined recently. It was emphasized that tourism has a stimulating effect on the socioeconomic development and it can be very helpful to raise the income level of the society in rural and underdeveloped regions. It has also been observed that rural areas initially participated to tourism sector only with their agricultural activities (Torres, 2003), and afterwards the rela- 
tionship between these areas and tourism sector started to grow and moved towards agri-tourism activities including accommodation in rural settlements and utilization of farm facilities. The bottleneck in the agriculture in the U.S.A. during 1980 s caused to the number of farmers started to decrease, many enterprises in the rural regions closed down and the remaining ones tried to obtain income through non-agricultural activities (Wilson, et al., 2001).

Having some differences among the definitions to define 'rural' as a complex concept (Gartner, 2004), tourism offers an alternative for the socio-economic development of rural areas by creating income flow through the regions in question (Yang, et al, 2010). Furthermore, rural tourism positively affects the income for agricultural family enterprises, offers local employments opportunities, and encourages local enterprises as small and medium size (Tew, Barbieri, 2012). As an institutional approach, European Union defines the rural tourism as "all tourism activities carried out in rural areas" (Roberts, Hall, 2003: 15). Contrary to the recent threat of a monotype lifestyle culture all over the world, rural tourism can easily be integrated into the other tourism types by its social, natural and agricultural coherence because of the attractiveness and varieties of rural inhabitants' local culture.

\section{The Development of Tourism in the Industrialization Process}

While the relative share of rural population in Turkey was $75 \%$ in 1950s, this share gradually decreased to $35 \%$ in 2000 s as the industry progressed over time. However, the employment rate in agriculture as a sector throughout the country increased to $29,5 \%$ and to $61,4 \%$ respectively in the countryside parts of Turkey. Moreover, it is significant that the unemployment rate in rural areas have a tendency to increase in contrast to that of urban areas, and "The 2006 Report" published by the State Planning Organisation (DPT) on rural development policies revealed that "the rate of labour participation in agriculture was decreased in rural areas". Such a decrease is a sign of a decline in rural economy production, and the rising unemployment rates in these areas confirm the importance of rural development projects that may prompt the agricultural and non-agricultural employment opportunities for especially among the young population.

Tourism sector is mostly considered as an industry consisting of the services designed to meet the changing demand patterns and needs of the citizens of developed western countries who have higher disposable income and extensive paid holidays. At international level, early forms of tourism demand were witnessed in the developed western countries, and afterwards, based on these developments and owing to the increased labour force in the destinations, the employees of mass production and subsequent eras were moved to the coastal areas. As a result of this course, these coastal areas became popular and available for all social classes when tour operators offered all-inclusive tour packages at lower prices and attractive conditions to meet this new demand. However, the demand profile for tourism of the higher income level social groups in industrialised countries began to change in 1990s. Tourism demand have directed to other types tourism offering more flexible and meaningful experience with more individualised and customised features than standard mass tourism in the past two decades (Briedenhann, Wickens, 2004). 


\section{Conceptual Framework: Rural Area and Rural Tourism}

The fact that the existence of higher population in rural areas than urban places is an important factor that makes the development a challenge for many countries (Un, et al., 2012). The term "rural area" literally means that the countryside spatial areas such as towns, villages and hamlets where the inhabitants cannot get satisfactory basic public services such as social security, education, health, employment opportunities, insurance, pension plans and cultural activities, as city dwellers usually can do, and their locations are generally away from urban settlements and metropolitan areas. Along with their natural and cultural structure, rural areas have tried to meet the increasing leisure needs of city dwellers for many years. Their natural features increase the interest of individuals to rural areas and it contributes to the development of rural tourism as a specific type of alternative tourism (Dogan, 2012:17). According to some authors, the major reasons about why rural tourism is necessary for rural development can be listed as (Akca, et al., 2001; Ross, Wall, 1999; Soykan, 2006; Koroglu, Koroglu, 2006; Emekli, et al., 2007:330);

- The protection of traditional occupations is highly crucial, because some of these occupations are mostly indigenous and they have almost disappeared in the course of time.

- Lots of new job opportunities can be created by the development of rural tourism.

- Rural tourism contributes to the expansion of some services such as information and public transportation.

- The government grants to the villagers as a contribution for their production is given not only for agricultural purposes; but some other local activities can also be supported by public authorities (e.g. the promotional support for some local products)

- Rural handicrafts have an important and essential place in the cultural heritage of country and region. These cultural elements can easily be converted into the tourism products via rural tourism.

- It is possible to take advantage of historical places (old churches, castles, farm buildings, houses) in different ways (as museum, handicraft center, accommodation house, etc.) in rural tourism.

- Since women had a limited role for their economic freedom in rural societies in the past, however they can play important roles in the economic activities even in rural tourism nowadays.

- Rural tourism provides important contributions for the protection of natural eco-systems while providing sustainable local development.

In order to develop rural tourism in any area, it is essential that the region should have high quality natural resources, transportation systems, convenient accommodation supply, original historical and cultural values along with natural beauties, adequate infrastructure services, various public and private services etc. Additionally, there must be some opportunities and promotional activities appropriate for different market segments (Kiper, 2006). In the literature, the effects of rural tourism for the development of a specific region are listed as the following (Liu, 2006; Navarro, et al., 2015; Yang, et al., 2010; Saxena, et al., 2007; Sharpley, 2007);

- It increases the quality and profitability of agricultural products.

- It raises the income of agricultural businesses and individuals who are working at agricultural activities and creates additional income for the region. 
- The fact that tourism is a part of service sector and it demands for a great amount of labour force, this industry offers a remedy for the unemployment problem in rural areas and it provides alternative additional job opportunities other than agriculture.

- As well as income generation, tourism leads to the positive consequences in the social lifestyle of local people (Busby, Rendle, 2000; Sharpley, 2002). In addition to economic benefits of tourism and effects on the social and cultural progress, it can also help to improve the quality of living standards and prosperity of the society by means of all other positive benefits, and it may contribute to protection of regional values.

\section{The Purpose and Methodology}

The basic purpose of this study is to present an alternative tourism option as a contribution to the economic, social and cultural recovery of the rural areas in Turkey, and in the case of Kandira region. As known, rural areas are the spatial areas usually called as villages and hamlets, etc. where agriculture is the major production activity. The natural and cultural structure of these areas has been the matter of interest of the city dwellers for many years, because the authentic ambiance of rural areas offers unique recreational and socio-cultural opportunities. And yet, the structure of the rural products is diversified and the varieties and quantities of these products have been increased over the past several years. So, the looking at the increases in demand for rural tourism in recent years, it is now clear that the demand for rural tourism will continue to rise for the forthcoming years in Turkey and there is a need to analyse these areas in terms of their sustainable tourism potential.

This study uses a non-empirical evaluative approach and mostly based on the related literature review and the situation analysis of rural tourism areas by on-site observation as methodology,. Thus, some of the qualitative data (information) was collected and recorded in the area by individual observations. Therefore, the study was basically organised as a theoretical approach which has been fostered from the literature on Rural Tourism. Based on this approach, this study was designed to develop a rural tourism growth model proposal for Kandira town and its surroundings. The model has been developed considering the rural tourism potential of the region and tries to explain how the model works best for the development of rural tourism in a sustainable way in the region.

\section{Sustainable Tourism Planning in Rural Areas}

The fact that tourism is defined as a potential development strategy in the economic studies carried out by the Organisation for Economic Cooperation and Development (OECD), emphasizes that there is a strong relationship between tourism and regional development (Dogan, Yildiz, 2007). However, focusing on the development more than ignoring the environment has resulted with unsatisfactory circumstances for many areas all over the world. Moreover, the irresponsible use of natural resources and degradation of cultural and environmental values throughout the world have brought the concept of sustainability on the agenda (Duran, 2011). The term "sustainability" is generally defined as "a state of balance in which human activities are in a harmony with their natural, social and cultural environment" (Kasli, et al., 2015: 29). The foundations for the concept of sustainable development were established in 1972, during the Stockholm Conference with the adoption of "principles emphasizing the bearing capac- 
ity of environment, minding generational equity in resource use, linking economic and social development to environment and emphasizing the unification of development and environment" (IULA-EMME, 1997, 3; cited in: Bozlagan, 2005). Sustainable development policies with ecological understanding should have three priorities (Bozlagan, 2005). These priorities are;

- Protection of ecological processes

- Use of resources in a sustainable way

- Preservation of genetic diversity.

The sustainability concept is also defined as "the ability of a society to maintain the ecosystem with their functions without any interruption, deterioration or overexploitation of the main resources of the system" (Karaman, 1996:102). Sustainable tourism concept, on the other hand, is a term that emerges from sustainable development and adaptation of this concept to tourism (Inskeep, 1991:461). Sustainability tries to unify the environment-related issues besides social and economic development in tourism industry (Kernel, 2005). The concept establishes many important links between environmental conservation and socio-economics (i.e. quality of life) but contentious issues include the balance between hard and soft sustainability (Johnson, 2002). However, some authors like Krippendorf (1987), assert that tourism can keenly adopt sustainability principles by considering the environmental responsibility and the integration of tourism with local peoples' expectations.

United Nations World Tourism Organization (UNWTO) defines sustainable tourism in a multidimensional way based on the needs of guests, industry, environment and host societies exactly taking into consideration its current and future economic, social and environmental effects, and etc. (Navarro, et al., 2015). Thus sustainable tourism focus current and future economic, social and environmental needs of visitors, industry, host communities (sdt. unwto.org:2017). Familiarly, sustainable results can be obtained without destroying the balance among the stakeholders demands from tourism (Navarro, et al., 2015; Sharpley, 2007:127). Sustainable tourism as a concept of meeting the local needs in consideration of the future opportunities (Avcikurt, 1997:136) integrates the sustainable principles respecting to the issues of environmental development capacity. It should accelerate not only the national economic growth, but also regional and local economic development (Inskeep, 1991:461). Rural tourism, in conjunction with sustainable tourism, needs to be maintained within particular principles. These principles can be summarized under six main categories as; improvement, utilization, design, rural economy, protection and marketing (Un, et al., 2012). According to the World Travel and Tourism Council (WTTC), in order for a touristic activity to be accepted as rural tourism, it should be executed in the rural area, and the vegetation in that area should be protected on the basis of sustainability (Kiper, 2006). In relation to this approach, Navarro, et al., (2015) listed and separated the benefits and the indicators of sustainability as; economic impacts of tourism development, socio-economic impacts of tourism development and environmental impacts in the context of sustainability (Navarro, et al., 2015). Lane (2005), on the other hand, argues that a successful sustainable rural tourism concept should be versatile and this goal cannot be achieved by the ineffective nature protection approach. For this purpose, there should be some basic principles of sustainable rural tourism, as the following;

- Protecting and maintaining the culture and character of local communities.

- Protecting and maintaining the landscape and habitats.

- Maintaining the rural economy.

- Maintaining a successful and permanent tourism industry. 
Like many other economic development strategies, tourism should be considered as a longterm strategy inherently, not short run policies in order to create the desired benefits in rural areas. To be successful in rural tourism strategy, it seems to be more rational to handle it with a strategic and sustainable approach without trusting the trends in demand or waiting for it to develop on its own. Eren (1990: 6) argues the term "strategy" as setting long-term goals, and then, allocating the necessary resources appropriately to reach these goals. While adopting rural tourism as a tool for economic and social development in a specific region, it is necessary to decide on the essential elements for successful tourism development. Consequently, it can be explained that, tourism development projects and programmes could have more than one objective and the balance among these purposes could be realized through effective and well-designed tourism strategies (Icoz, et al., 2009:195). Since tourism attractions and resources in a region may differ from those in another region, each region can determine its own tourism development strategy and rank the goals of these strategies based on their relative importance. For instance, a rural region, village or town which has adequate attractions and infrastructures, may give a priority to create awareness and appropriate image using various promotional methods and advertisements in their strategic plans, or on the contrary, a region may decide to improve the local attractions and infrastructure in the area as its priority.

\section{Models Developed for Rural Tourism}

In the literature, there are various models suggested by the authors about the development of rural tourism areas which could be a basis for this study. These models are designed taking some important factors into consideration such as industrial development, labour need, infrastructure and topography of the area involved, primarily geographical structure of the location. Pröbstl-Haider, et al. (2014) mentioned four different models or approaches for different rural areas depending on the expectations of locations as briefly summarized below;

- Lighthouse model: In this model, most of the rural landscape, with its farms, traditions and culture, remains unspoiled by tourism. The major driver for new job opportunities and services in the rural countryside is one single large tourism project. This model promises positive economic and social effects, but might also have negative effects on landscape beauty and natural integrity.

- Small-scale land use model: Typical for this model is the integration of tourism within the existing agricultural land uses. Many farmers are increasingly realizing the additional economic benefits that can be gained from diversifying into providing farm stays on their land.

- Zoning model: This model is based on the idea of promoting the outstanding natural beauty and integrity to visitors. One major precondition for using this concept in tourism is to obtain a certificate for these valuable landscapes before they can be promoted as an integral part of the region. This model allows the clear demarcation of these special natural areas of diversity, the habitats of endangered species, or even remaining "wilderness".

- Thematic model: Existing structures and buildings as well as cultural aspects, religious and traditional entities are the main components in this model. The tourism concept connects this infrastructure to an entire product. To illustrate, such typical examples as Castle Road, Cheese Road, Historical Railway and Wine Road are included within this scope. Features based on the traditional culture, like historical gardens, mountain 
houses, cheese production and vineyards will help a region to become a brand in a short time possible. Successful leadership for the thematic model typically implies top - down planning and management as well as joint marketing and permanent quality control.

\section{A Rural Tourism Model Proposal for Kandira Residential Area}

Kandira, with its $52 \mathrm{~km}$-long coastal area, is located within the borders of Kocaeli city, surrounded by Sakarya (Adapazari) city on the east, Istanbul city on the west, Izmit (Kocaeli) city center on the south and the Black Sea on the west (Anonymous, 2015). The topography of Kandira is covered with small hills and in the shape of apparent land; it is subject to the effect of Blacksea climate. There are villages with high rural landscape values in Kandira. Some examples are Agacagil and Akcakese villages with their genuine houses and roads including inlaid stones dating back to Ottoman Empire; Akcaova, Akinci and Bagirganli Villages with their leadership in Kandira stone production; Cebeci village with its wide and shallow blue flag coasts; Kefken with its pink rocks in interesting geological forms; and Kerpe with its historical port (Uzumcu, et al., 2015).

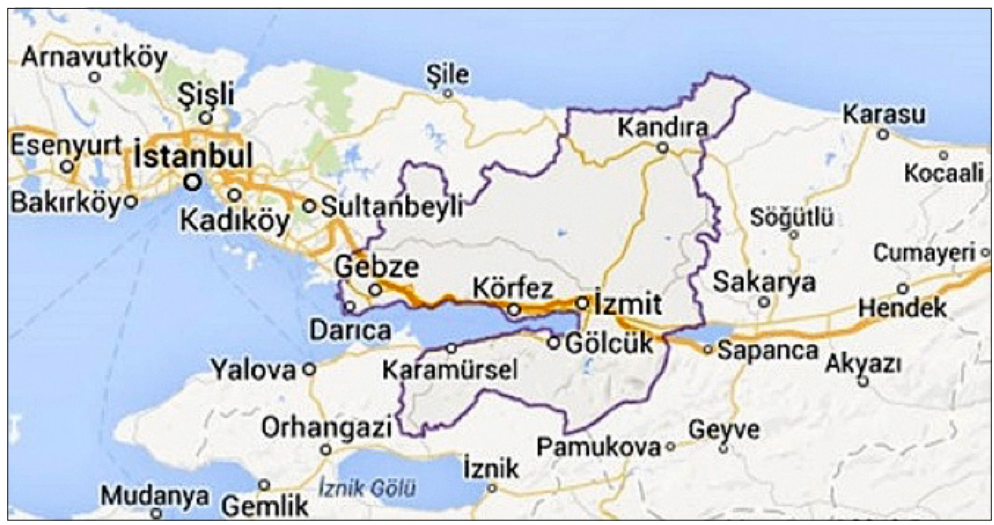

Figure 1. Map and location of Kandira Region

Fishing is the main economic activity and one of the limited income sources of Kefken and Bagirganli residents. In the villages of Kandira, communities continue their lives there being loyal to their traditions and customs. Traditional houses in the villages of Kandira are mud and wood mixture structures with two floors, generally a stable on the ground floor where the landlord's livestock are kept and a house on the first floor where family members live in. In every village, there are some old school buildings including a guest house for accommodation inside. However, these school buildings have been remained idle for a long time in spite of their availability for education, because of the teaching by transportation system for regional students (transporting students to other places for education purposes) (Uzumcu, et al., 2015).

Considering the socio-cultural structure and geographical structure of Kandira, it will be necessary to employ more than one of the above-listed models. The population in Kandira is 48.937 (http://www.nufusu.com) but subject to emigration, mostly to Kocaeli-İzmit center. Since the land is highly valuable in that region, it has been sold at higher prices to obtain monetary earnings instead of dealing with agriculture; therefore, mostly old and retired people have stayed in the town and the young people have emigrated to other regions quitting their usual 
places because of local high unemployment rates. In the town and its villages on the coastal areas, marine tourism services are offered to domestic visitors most of whom coming from Istanbul in small motels and boarding houses only in July and August. However, experts stated that it is necessary to inform and encourage the community and stop emigration of the young people from the town for a desired development of rural tourism. It is also suggested that the institutions should support the town by encouraging investments in the area and government executives should complete tourism reconstruction plans immediately. As for the local community, since tourism is not well-known outside coastal villages, it is definitely necessary to inform and convince the local people that they will get important economic benefits as long as necessary training and encouragement are given to them in order to be able to carry out rural tourism activities (Uzumcu, et al., 2015).

Table 1. SWOT Analysis of Rural Tourism in Kandira

\begin{tabular}{|c|c|}
\hline Strengths & Weaknesses \\
\hline $\begin{array}{l}\text { - Historical background } \\
\text { - Logistic advantages for domestic and foreign } \\
\text { markets } \\
\text { - Community support for tourism } \\
\text { - Safe environment for tourists } \\
\text { tradesmen } \\
\text { - Natural resources and unspoilt environment for } \\
\text { ecotourism / rural tourism } \\
\text { - Location within the borders of a metropolitan } \\
\text { - Improved cooperation among stakeholders }\end{array}$ & $\begin{array}{l}\text { - Failing to create a tourism product package; lack of effective } \\
\text { - } \text { promotion and marketing } \\
\text { - } \text { Lack of qualified tourism businesses } \\
\text { - Labour shortage } \\
\text { - Inadequate amount of complementary service businesses } \\
\text { - Electricity interruptions time to time } \\
\text { - Lack of touristic activities in businesses and Kandira } \\
\text { - } \text { Narrow and winding roads } \\
\text { - } \quad \text { Carrying capacity problems at weekend holidays } \\
\text { - Inefficient utilization of gastronomic varieties } \\
\text { - Unsolved reconstruction problems } \\
\text { - Lack of educational institutions to train qualified labour force } \\
\text { in Kandira }\end{array}$ \\
\hline Opportunities & Threats \\
\hline $\begin{array}{l}\text { - Being open to different tourism activities in the } \\
\text { region } \\
\text { Increasing popularity of Ecotourism / Rural } \\
\text { tourism } \\
\text { - A powerful product such as unspoiled nature } \\
\text { with rural tourism potential and preserved } \\
\text { cultural texture } \\
\text { - Availability of tourism-related projects, } \\
\text { applications and incentives by a number of } \\
\text { institutions, primarily having a prominent brand } \\
\text { name }\end{array}$ & $\begin{array}{l}\text { - A perceived local image as a cheap and daily use holiday } \\
\text { - } \text { Envination } \\
\text { - Unplanned construction } \\
\text { - Unplanned agricultural and livestock activities } \\
\text { - } \text { Destruction of the areas covering natural attractions } \\
\text { - } \text { Failure to develop rural tourism architecture } \\
\text { - } \text { Availability of other regions offering similar tourism products } \\
\text { - } \text { uncontrolled areas } \\
\text { - } \text { Prevailing marine oriented tourism mentality } \\
\text { - Lack of travel intermediary businesses }\end{array}$ \\
\hline
\end{tabular}

Source: Kasli et al. (2014).

Uzumcu et al., (2015) indicated that although Kandira has rich fertile and arable lands, these lands are not efficiently utilized or the cultivated parts of land are used irresponsibly and present production is inadequate to meet the needs of local people as products don't provide any important economic benefit. Rural tourism can enable the natural, social and cultural resources for economic and social development in the town. The town is of a deep-rooted historical background, possessing specific features like the ruins of historical port, castles, pirate caves, etc., and holds unique handicraft samples. Agacagil village can be considered a tourism 
location as well as Bagirganli, Kefken, Kerpe, Cebeci, Sarisu, Pinarli and Kincirli villages which have marine tourism potential, in order for successful execution of sustainable touristic activities in Kandira (Uzumcu, et al., 2015). In this sense, rural tourism in Kandira and villages has been evaluated in a SWOT analysis of the region as shown in Table 1.

Kandira is a quite large town with its 90 villages and a significant destination for visitors based on its convenient coastal area and unspoilt natural resources besides its historical and cultural values. Especially, it has a great geo-political importance with its close proximity to especially big industrialized cities such as İstanbul, Sakarya, Yalova and Kocaeli. Therefore, this destination has been offering traditional ${ }_{3} \mathrm{~S}$ tourism services at weekends and during the high summer season for relatively short periods for many years. Kandira with its surroundings as a convenient destination for nature-oriented tourism types like rural tourism, ecotourism and gastronomy tourism which are very popular in Turkey recently can be further developed by sustainable rural tourism activities. As stated by Uzumcu et al., (2015), Agacagil village, located on the coastal area and as a museum like-village in a sense with its traditional houses, square and nature, can be participated to Kandira tourism through a thematic model with a sustainability understanding, protecting its unspoilt rural areas and continuing agricultural production, unless its rural texture is destroyed.

In this study, a rural tourism model was devised and suggested in order to provide a contribution to the regional development of rural tourism as an alternative form for the mass tourism that already exists in the region. Additionally, the model was inspired from the different models previously mentioned in this paper and it does not ignore the mass tourism which is already dominant in the region. The ultimate target of the model is to become a guide in relation for making local community to have some economic and social benefits from tourism activities in the destination by using local, natural, rural and traditional resources they hold.

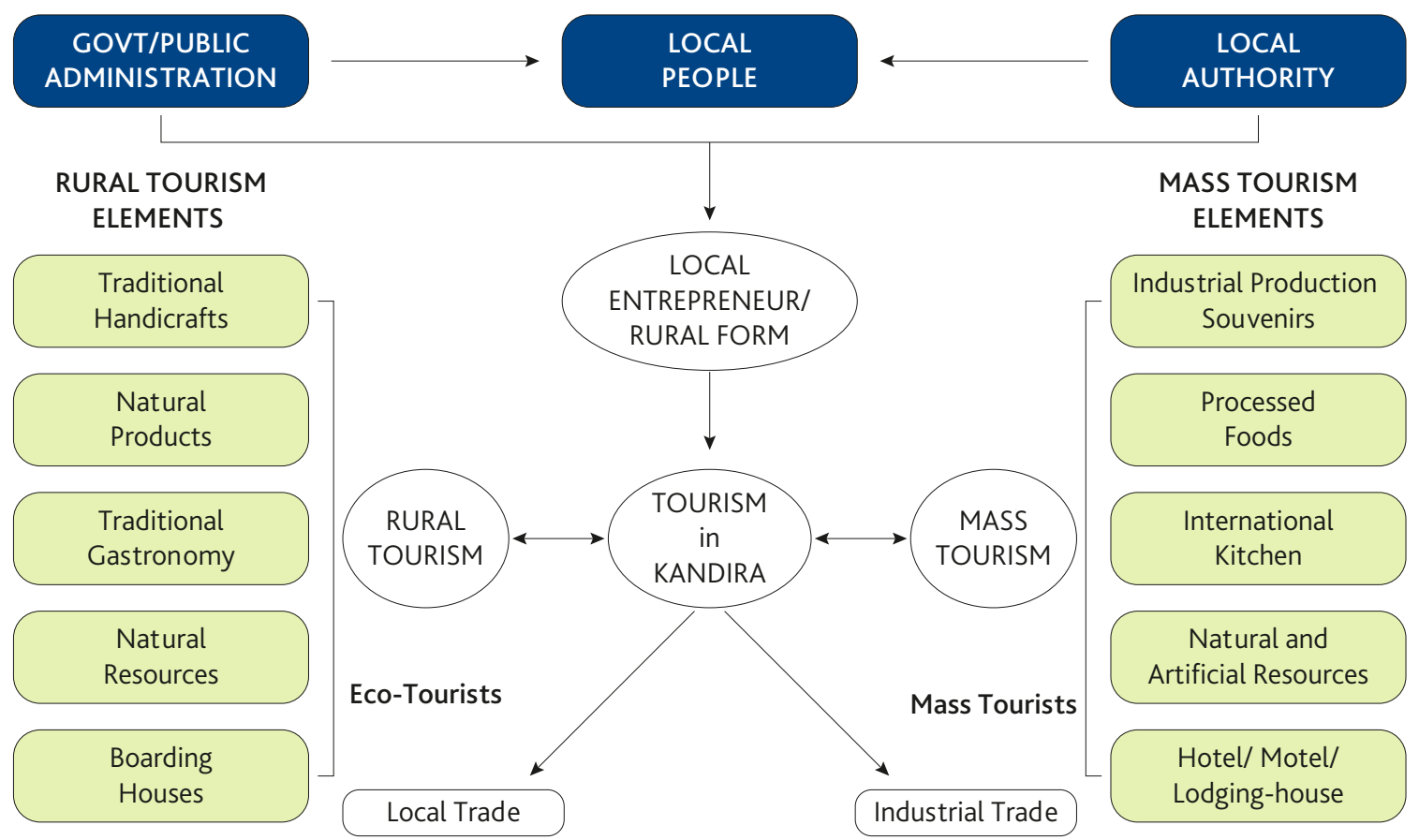

Figure 2. Kandira Rural Tourism Development Model 
The model is shown in the Figure 2 and the following paragraphs explain how the model works efficiently.

Kandira Rural Tourism Development Model (KRTDM) is of six core elements as; government - public administration, local people, local authority, entrepreneur (rural), rural tourism and mass tourism elements. As seen in the Figure 2, local people and local entrepreneurs are on the centre of the model. This means that these elements have more effective and efficient roles for start-up and run the rural businesses by combining the elements from rural industry and tourism industry when needed. The role of the public administration will be supportive in the model. Lack of financial support, information, education in business issues and lack of skills etc. of locals can be considered as the factors need to be stimulated by the government authority. The government authority is the synonymous with the public administration of the county and the region. In the entire region, the areas or the rural tourism units can be defined as per their priorities and with the desire of locals to start their rural business. Public administration encourages locals to engage in rural tourism as entrepreneurs. Its role is also encouragement of rural business forms by coordinating them. Public and local authority can train these groups about the legal issues before and after start up the business and provide continuing education programmes for the effective management of their businesses.

The model aims to satisfy the needs and expectations of the local people as much as possible. Particularly, the expectations of local community can more easily be met through the rural tourism, since the structure of the region is rural and thus the model contains the basic rural elements as inputs combining local natural products, gastronomy, traditional handicrafts, rural culture and traditional products etc. Local people may be directed to revive, sustain and produce authentic, natural and traditional products which will be the core elements of rural tourism product. The production and sales of local traditional goods in addition to the services which will be offered and provided in the rural business units can be planned for the interior visions.

In the model, rural tourism units as accomodation, local restaurants and cousines and rural attractions are considered as the core business forms and it doesn't ignore and eliminate the current tourism forms in the region. It can clearly be seen that the current form of tourism in Kandira is the mass tourism and the model does not ignore this existing form of tourism in the coastal area of the region as well. Mass tourism in the region is mostly concentrated on the tourist accommodations at hotels and guest houses in Bagirganli, Cebeci, Kefken, and Kerpe areas which are the villages located on the coastal area of Kandira as a destination reflecting a very short peak season from July to August. Similarly, the mass tourism in the coastal areas of Kandira is mainly based on the consumption of industrially processed food products which may remain inadequate to meet the needs of locals as they expected.

The successfully run of the model heavily depends upon the efforts of local people and the entrepreneurs who are interest in or encouraged to start up the rural tourism business. Entrepreneurs may obtain the required business plan from the local authorities and public administration in case they do not have it or instead, a business plan may be prepared collaboratively. The model aims the local entrepreneurs to combine the rural elements available in the location. For this purpose, the rural characteristic of Kandira enables and offers some necessary inputs, such as traditional unique local cousine, unspoilt nature, local architecture, traditional handmade products, homemade foods, etc. to the local entrepreneurs. The model also is taking into account the different rural tourism development models already mentioned in the previous sections of the paper. For example, a local entreprenur can start his or her business up in the Old Train Station or in any other historical building. In the further steps of the process, 
the increase in the number of local entrepreneurs may be an inevitable result of the process in the region. So, the close collaboration of rural tourism entreprenurs and further cooperations among them may easily be established by this project. Taking the existing mass tourism in the region into the consideration may give an alternative customer base to the rural tourism units that they already established. It may highly be possible to acquire these existing consumers with new rural tourism businesses, because they will offer more appropriate form of tourism products as alternative in the region. The mass tourism marketing structure may facilitate the spatial distribution of the rural tourism. In summary, the suggested model requires the harmonious combination of all the elements in order to work collectively and more effectively.

\section{Conclusion and Comments}

This study specifically focuses on a model proposal for sustainable tourism development in the rural areas in Kandira as a significant destination for both domestic and foreign visitors based on its unspoilt coastal areas, natural resources, historical and cultural values. And also being located very close to industrialized cities such as Kocaeli, Istanbul and Sakarya, Kandira welcomes traditional ${ }_{3} \mathrm{~S}$ (Sun, Sea, and Sand) tourists at weekends mostly in the peak/high season (mostly summer). Furthermore, Kandira is open to create a potential for nature based tourism demand with its rural areas, agricultural production, rural texture, thematic historical patterns etc.

The model proposal is an overall model reckoning the Lighthouse, Zoning and Thematic models and it was devised by considering the opportunities which are available in the region in terms of natural, rural, traditional resources and the latest trends in tourism demand for the nature. Likewise, the model specifically considers the local community and their difficulties to start up a business, and general conditions for their inclusion to tourism. Furthermore, it also aims to meet the expectations of different shareholders such as locals, local authorities, entrepreneurs and public administration and potential visitors for rural tourism.

As many authors mentioned, tourism is an effective tool for the development of rural areas and it is also very effective for the empowerment of these areas in terms of their socio-economic and cultural structure, since the people who live in the areas have lost their skills by doing the traditional routine agricultural activities and the contribution of agriculture to their welfare is not satisfactory nowadays. For this reason, a different development plan is inevitably needed, and the plan should contain a sustainable approach which maintains the local culture, landscape, habitat and the rural economy. Sustainable products that are in a harmony with the local environment, society and culture should principally be the products that meet the current needs of local people. The model proposal for Kandira is an area specific tourism model that considered the rural tourism resources of the Kandira region itself. Since tourism attractions and resources are mostly different from one region to another, each region can determine its own tourism development strategies and the goals of these strategies according to their relative importance. In order to obtain the desired benefits for nature based tourism in Kandira, tourism should be perceived as a long-term strategy inherently, avoiding short-term approaches. After the historical perspective is presented an argument is made that current rural tourism development practices rely on an old paradigm, which is to use local attributes as the primary basis for development and marketing strategies. This has led, in recent years, to a great deal of development attention being paid to the cultural/heritage attributes of a place. Using research conducted in the state of Minnesota on highway travellers and tourists to rural des- 
tinations, a new way to look at actual and potential visitors is offered. Instead of an attribute-specific development approach, a benefits-based model is suggested as a different way to position rural tourism destinations. After the historical perspective is presented an argument is made that current rural tourism development practices rely on an old paradigm, which is to use local attributes as the primary basis for development and marketing strategies. This has led, in recent years, to a great deal of development attention being paid to the cultural/heritage attributes of a place. Using research conducted in the state of Minnesota on highway travellers and tourists to rural destinations, a new way to look at actual and potential visitors is offered.

Instead of an attribute-specific development approach, a benefits-based model is suggested as a different way to position rural tourism destinations In order to achieve the above mentioned goals, the followings are the suggestions to the regional managers of public and private organisations and major decision makers:

- Considering the demand for organic products and more environmentally conscious tourist profile than ever, quality of the local products should be established rather than quantity as a priority. To do so, small-scale family farms and businesses can be protected from outside competitors through investments and incentives in the region.

- Some of the renovations should be started in Agacagil and the surrounding villages with the well-developed tourism projects, and boarding houses, traditional meals and organic products should be encouraged for local development. The women and the young people in the region can be encouraged to participate in production; agricultural products like water buffalo yoghurt, cheese, darti (a kind of dairy product), fruits-vegetable and village bread can be produced.

- Most of the people are not well-aware of tourism in Kandira, other than those living in the coastal villages. Therefore, it is essential to inform, train and convince them by public bodies in order to motivate rural tourism in the region.

- Local people should be employed in rural tourism related businesses and works like production of souvenirs and regional handicrafts (Kandira fabric, Kandira stone, etc.).

- The implementation and finalization of tourism reconstruction plans in the town and the incentives for tourism investments should be encouraged by the public and local authorities.

- The number of complementary services (public services, health services etc.) that will help for tourism development in the area should be developed both in quality and quantity.

- Eliminating the inadequacies in infrastructure and superstructure around the village squares, and renovating them under the supervision of public or local authorities; authentic houses should be allocated to rural tourism as a model for encouragement of local people.

- The protection of Kandira fabric and Kandira stone and production of local delicacies should be supported by local public authorities.

- Local public authorities should work in collaboration with the universities and other institutions as prospective stakeholders; businessmen and local people should be informed and trained about rural tourism.

Decision-makers and planners should consider not only the potential economic dimension and benefits, but also the natural, social, cultural and environmental aspects of rural tourism. Rural tourism may bring significant benefits to these areas and inhabitants who live there, as long as authorities who are responsible for regional development do not ignore the sustainable 
regional planning, and do meet the expectations of local parties and people, adopting a participative and sustainable insights. Finally, this study, in a theoretical approach, tries to emphasize the importance of sustainable tourism, suggesting the rural tourism development in specific countryside areas in order to balance environmental sensitivity and tourism development issues as two important concepts of the century we live in.

In accordance with the main purpose, this study is limited to a single geographical area and destination. It would be much better to examine the different destinations and their competitiveness in terms of their rural tourism potentials. As other limitations, there is no quantitative data directly collected from local people and businesses, and a few number of people contacted to have info about the basic problems of the area.

For future researches, it is recommended that the further studies could provide some empirical data which will be gathered from local inhabitant, government authorities, investors both local and outside etc., in terms of their insights about how to best match sustainability and tourism as a development option for rural areas. These studies could also encompass more than a specific geographical area or destination for comparative analyses, and perhaps the best way would be the research which combine the qualitative and quantitative analyses at the same time in the long term. Moreover, it would be exciting to analyse what factors influence the demand for rural tourism at national and international level in these types of destinations.

\section{References}

Akca, H. Esengun, K., Sayili, M. 2001. The role of Rural Tourism on the development of rural areas. Standard Dergisi 40/470, 29-34. (in Turkish)

Avcikurt, C. 1997. Turkish Tourism on the European Union integration process,- Problems and Solutions. Unpublished Ph.D. Dissertation, Balikesir University, Graduate School of Social Sciences - SBE, Balikesir. (in Turkish)

Bahce, S. 2009. Cultural Heritage tourism model on the development of rural areas. Dumlupinar Universitesi, Sosyal Bilimler Dergisi 25, 1-12. (in Turkish)

Bozlagan, R. 2005. The Historical background of Sustainable Development thought. Sosyal Siyaset Konferanslari Dergisi 50, 1012-1028. (in Turkish)

Briedenhann, J., Wickens, E. 2004. Tourism routes as a tool for the economic development of rural areas - Vibrant hope or impossible dream? Tourism Management 25/1, 71-79.

Busby, G., Rendle, S. 200o. The transition from tourism on farms to Farm Tourism. Tourism Management 21(6), 635-642.

Cetin, I. 2015. Agritourism development model for Northern Cyprus. Journal of Recreation and Tourism Research 2 (2), 1-11.

Dogan, G. 2012. The examination of Rural Tourism potential for Ayas town of Ankara province. Ankara University, Graduate School of Science, Unpublished Master Thesis, Department of Agricultural Economics, Ankara. (in Turkish)

Dogan, S., Yildiz, Z. 2007. Regional Development and Tourism relationship and a research on the use of alternative tourism potential for the development of Lakes District. Suleyman Demirel Universitesi Sosyal Bilimler Enstitusu Dergisi 6, 147-181. (in Turkish)

Duran, E. 2011. Tourism, Culture and Idendity relationship; Sustainability of socio-cultural identity in tourism. Istanbul Ticaret Universitesi, Sosyal Bilimler Dergisi 10/19, 291-313. (in Turkish) 
Emekli, G., Sudas, I., Soykan, F. 2007. Migration, Rural Development - Rural Tourism and Turkey. Ataturk Kultur, Dil ve Tarih Yuksek Kurumu, 38. ICANAS (Uluslararasi Asya ve Kuzey Afrika Calismalari Kongresi) Kentlesme Cevre Sorunlari ve Cozumleri - 1.- Vol, Bildiriler (Congress Proceedings), Ankara / Turkiye. (in Turkish)

Eren, E. 1990. Strategic Planning and Management in Businesses. İstanbul Universitesi Yayini, İstanbul. (in Turkish)

Gartner, W.C. 2004. Rural tourism development in the USA, International Journal of Tourism Research 6 (3), 151-164.

Hudman, E. L. 1992. The role of tourism and environmental problems - An approach to potential effects. Turizm ve Cevre, TUGEV 24, 25-34 (in Turkish)

Inskeep, E. 1991. Tourism planning; an integrated and sustainable development aproach, Van Nostrand Reinhold, New York.

Icoz, O., Var, T., Ilhan, I. 2009. Tourism Planning and Policies: Regional Planning in Tourism. Turhan Publishing, Ankara. (in Turkish)

Johnson, D. 2002. Environmentally sustainable cruise tourism: A reality check. Marine Policy 26/4, 261-270.

Karaman, A. 1996. Ecological framework for sustainable tourism planning: Sustainable Tourism: An ecological approach to tourism planning, 19th World Urbanisation Day Colloquium, Mimar Sinan University, Istanbul. (in Turkish)

Kasli, M., Ilban, M.O., Ekici, A. 2014. Kandira Tourism Master Plan: 2015-2023, Kandira Kiyi Bandi Kultur ve Turizm Koruma ve Gelisim Bolgesi Birligi, Kandira, Kocaeli. (in Turkish)

Kernel, P. 2005. Creating and implementing a model for sustainable development in tourism enterprises. Journal Cleaner Production 13/2, 151-164.

Kiper, T. 2006. The evaluation of the landscape potential of Safranbolu Yorukkoyu in terms of Rural Tourism. Ankara University, Graduate School of Science, Department of Landscape Architecture, Unpublished Ph.D. Dissertation, Ankara. (in Turkish)

Koroglu, A., Koroglu, O. 2006. The role of Rural Tourism on the Regional Development: Rural Tourism potential of Buldan town, Buldan Sempozyumu Bildiri Kitabi 22-24 Kasim, (Symposium Proceedings)1, 233-242. (in Turkish)

Krippendorf, J. 1987, Ecological approach to tourism marketing. Tourism Management 8 (2), 174-176.

Lane, B. 2005. Sustainable rural tourism strategies: A tool for development and conservation, RIAT Revista Interamericana de Ambiente Turismo. Interamerican Journal of Environment and Tourism 1, 12-18.

Liu, A. 2006. Tourism in Rural Areas: Kedah, Malaysia, Tourism Management 27 (5), 878-889.

Met, O. 2012. Development with tourism: A tourism development strategy proposal for Sinop. Karadeniz Arastirmalari Dergisi 34, 163-179. (in Turkish)

Navarro, M., Pedraja, M., Vinzon, M.I. 2015. Sustainability indicators of rural tourism from the perspective of the residents, Tourism Geographies 17(4), 586-602.

Orams, M.B. 1995. Towards a more desirable form of eco-tourism. Tourism Management 16/1, 3-8.

Pröbstl-Haider, U., Melzer, V., Jiricka, A. 2014. Rural tourism opportunities: Strategies and requirements for destination leadership in peripheral areas. Tourism Review 69/3, 216-228.

Roberts, L., Hall, D. 2003. Rural Tourism and Recreation: Principles to Practice. CABI Publishing. U.K.

Ross, S., Wall, G. 1999. Ecotourism: Towards congruence between theory and practice. Tourism Management 20, 123-132. 
Saxena, G., Clark, G., Oliver, T., Ilbery, B. 2007. Conceptualizing integrated rural tourism. Tourism Geographies 9/4, 347-370.

Sharpley, R. 2002. Rural tourism and the challenge of tourism diversification: the case of Cyprus. Tourism Management 23, 233-244.

Sharpley, R. 2007. Flagship attractions and sustainable Rural Tourism development: The Case of the Alnwick Garden, England. Journal of Sustainable Tourism 15/2, 125-143.

Soykan, F. 2006. Avrupa'da kirsal turizme bakis acisi ve kazanilan deneyim (in Turkish), II.Balikesir Ulusal Turizm Kongresi, 20-22 Nisan 2006, Bildiriler Kitabi (Congress Proceedings), Balikesir, 71-87

Tew, C., Barbieri, C. 2012. The perceived benefits of agritourism: the provider's perspective. Tourism Management, 33 (1). pp.215-224.

Torres, R. 2000. Linkages between tourism and agriculture in Mexico. Annals of Tourism Research 30 (3), 546-566.

Un, E., Tutar, F., Tutar, E. Erkan, C. 2012. The role of rural tourism on economic development. International Conference on Eurasian Economies, Conference Proceedings, 345-350.

Uzumcu, T.P., Celik, A., Otar, S., Hacioglu, A. 2015. The use of rural areas for tourism purposes: The case of Kocaeli, Kandira. International Journal of Social and Economic Sciences 5 (2): 92-102.

Wilson, S., Fesenmaier, D.R., Fesenmaier, J., Van Es, J.C. 2001. Factors for success in rural tourism developmen. Journal of Travel Research 40 (2), 132-138.

Yang, Z., Cai, J., Sliuzas, R. 2010. Agro-tourism enterprises as a form of multi-functional urban agriculture for peri-urban development in China. Habitat International 34 (4) 374-385.

Internet 1: http://sdt.unwto.org/content/about-us-5 (02.01.2016.)

Internet 2: http://www.ecotourism.org/what-is-ecotourism (19.05.2013.)

Internet 3: http://www.nufusu.com/ilce/Kandira_kocaeli-nufusu (21.02.2016.) 